\title{
The Performance of Port Clusters
}

\author{
Peter W. de Langen*
}

\begin{abstract}
This paper deals with the performance of port clusters. Port clusters are analyzed using a framework that draws from different schools that deal with clusters (see De Langen, 2004). Central to the framework is the identification of eight variables of cluster performance. Four of those-agglomeration and disagglomeration forces, internal competition, heterogeneity of the cluster and the level of entry and exit barriers - are related to the structure of a cluster and fourthe presence of trust, the presence of intermediaries, the presence of leader firms and the quality of collective action regimes-are related to the governance of clusters. The validity of these variables is confirmed in three case studies, of the port clusters of Rotterdam, Durban, and the lower Mississippi. The strengths and weaknesses of the three port clusters, the importance of the variables discussed above and opportunities for policy and management to improve the performance of clusters are discussed. The results of this study are relevant for cluster scholars and for scholars specializing in port studies and, since implications of this study for policy and management in (port) clusters are discussed, the study is also relevant for (port) cluster managers and for managers of firms in (port) clusters.
\end{abstract}

Keywords: Agglomeration, Clustering, Durban, Port Clusters, Rotterdam, Lower Mississippi Ports.

\section{INTRODUCTION}

Economists frequently use the cluster concept to analyze the economic development of regions. Because of increasing interaction and competition between regions, the specialization of regions increases. This leads to the development of clusters: spatial concentrations of interrelated firms. Competitive clusters can contribute substantially to the economic development of regions. Therefore, the question 'what determines the performance of clusters' is relevant.

The cluster concept is frequently applied, but hardly ever to seaports, in spite of the fact that seaports are clear examples of clustering. Virtually all ports attract firms related to the arrival of goods and ships.

The subsequent paper consists of three parts. Part II briefly discusses insights on the performance of clusters, derived from various schools and presents a framework

- Port Economist, Department of Regional, Port and Transport Economics, Erasmus University Rotterdam P.O. Box 17383000 DR Rotterdam, The Netherlands. E-mail: delangen@few.eur.nl 
to analyze clusters. Then Part III applies these insights to seaports and Part IV presents conclusions.

\section{A FRAMEWORK TO ANALYZE CLUSTER PERFORMANCE}

A widely accepted theory on relevant variables of cluster performance is lacking. At least four relevant schools provide insights that can be are used to develop a sound analytical framework for examining cluster performance (see De Langen, 2004). The variables for the performance of clusters are derived from these four schools.

A distinction is made between 'governance variables' and 'structure variables'. The first group includes all variables that are directly related to the behavior of organizations in the cluster; and the second group includes all variables for which this is not the case. Four 'structure variables'-agglomeration and dispersion forces, internal competition, cluster barriers and cluster heterogeneity - and four governance variables - trust, leader firms, intermediaries and collective action regimes - are identified. The effects of all these variables on the performance of clusters are summarized in the Tables 1 and 2.

Table 1. The Effects of Cluster Structure on Cluster Performance

\begin{tabular}{|c|c|}
\hline $\begin{array}{l}\text { Element of cluster } \\
\text { structure }\end{array}$ & Effect on cluster performance \\
\hline \multirow{5}{*}{$\begin{array}{l}\text { Agglomeration } \\
\text { economies } \\
\text { (see Krugman, 1991) }\end{array}$} & A shared labor pool attracts firms to the cluster. \\
\hline & The presence of customers and suppliers attracts firms to the cluster. \\
\hline & The presence of knowledge (spillovers) attracts firms to the cluster. \\
\hline & Land scarcity and high land prices 'disperse' firms from the cluster. \\
\hline & Congestion disperses firms from the cluster. \\
\hline \multirow{3}{*}{$\begin{array}{l}\text { Internal } \\
\text { competition } \\
\text { (see Porter, 1990) }\end{array}$} & Internal competition prevents monopoly pricing. \\
\hline & Internal competition leads to specialization. \\
\hline & Internal competition promotes innovation. \\
\hline \multirow[t]{2}{*}{ Cluster barriers } & $\begin{array}{l}\text { Entry barriers (such as inaccessible networks) and start-up barriers (such as non- } \\
\text { availability of local venture capital) reduce competitive pressure and prevent the inflow of } \\
\text { (human) capital. }\end{array}$ \\
\hline & $\begin{array}{l}\text { Exit barriers (such as 'sticky labor' and cluster specific investments) reduce uncertainty } \\
\text { for firms in the cluster. }\end{array}$ \\
\hline \multirow{3}{*}{$\begin{array}{l}\text { Cluster } \\
\text { heterogeneity } \\
\text { (see Metcalfe, 1994) }\end{array}$} & Cluster heterogeneity enhances opportunities for innovation. \\
\hline & Cluster heterogeneity enhances opportunities for cooperation. \\
\hline & Cluster heterogeneity reduces vulnerability for external shocks. \\
\hline
\end{tabular}


Table 2. Variables for the Quality of Cluster Governance

\begin{tabular}{l|l}
\hline $\begin{array}{l}\text { Elements of cluster } \\
\text { governance }\end{array}$ & Effects on cluster performance \\
$\begin{array}{l}\text { The presence of trust } \\
\text { (see Nooteboom, } \\
1999)\end{array}$ & $\begin{array}{l}\text { Trust lowers coordination costs because costs to specify contracts decrease. } \\
\text { Trust increases the scope of coordination beyond price, because the risk of free } \\
\text { riding decreases. }\end{array}$ \\
\hline $\begin{array}{l}\text { The presence of } \\
\text { intermediaries (see } \\
\text { Nooteboom, 1999) }\end{array}$ & $\begin{array}{l}\text { Intermediaries lower coordination costs and increase the scope of coordination } \\
\text { beyond price because they specialize in managing coordination. }\end{array}$ \\
\hline $\begin{array}{l}\text { The presence of } \\
\text { leader firms (see }\end{array}$ & $\begin{array}{l}\text { Leader firms generate positive external effects for firms in their network, mainly } \\
\text { by encouraging innovation and promoting internationalization. }\end{array}$ \\
\cline { 2 - 2 } $\begin{array}{l}\text { De Langen and } \\
\text { Nijdam, 2003) }\end{array}$ & $\begin{array}{l}\text { Leader firms generate positive external effects for firms in the cluster, mainly by } \\
\text { organizing investments in the training and education infrastructure, the } \\
\text { innovation infrastructure and the infrastructure for collective action. }\end{array}$ \\
\hline $\begin{array}{l}\text { Quality of } \\
\text { collective action } \\
\text { regimes (see Olson, } \\
\text { 1971) }\end{array}$ & $\begin{array}{l}\text { The more resources are invested in the collective action regimes, the better the } \\
\text { performance of a cluster. Five variables influence the amount of resources } \\
\text { invested: the role of leader firms, the role of public organizations, the presence } \\
\text { of an infrastructure for collective action, the presence of a community argument } \\
\text { and the use of voice. }\end{array}$ \\
\hline
\end{tabular}

The insights derived from these cluster studies are applied to seaport clusters. The results of this study are discussed in the following section.

\section{THE PERFORMANCE OF PORT CLUSTERS: EMPIRICAL FINDINGS}

Rarely, has the cluster concept has been applied to seaports. Relevant studies are those of Haezendock (2001) on the strengths and weaknesses of Antwerp's port cluster, Van Klink (1995) on the development of port networks, and Slack (1989), among others, on the location behavior of port service industries. The empirical research in this study contributes to port studies in a number of ways: the application of new insights from cluster theories to ports, attention to the issue of governance in seaports, a comparison between different port clusters, and an analysis of implications of using the cluster perspective for policy and management in seaports.

The arrival of ships and cargo is central to port clusters. Incoming goods and ships attract different economic activities that can be distilled into five components. The first component is cargo handling, comprising all activities necessary to load and unload ships, such as terminal operators, pilots, towage and mooring. The second component is transport and includes all firms that facilitate the movement of goods, such as shipping lines, shipbrokers and trucking firms. The third component is logistics and includes all activities that add value to the transported products, such as storage, re-packing and blending. The fourth component consists of a specific set of manufacturing activities. The most important manufacturing activities are oil refining, chemicals production and steel plants. The fifth component consists of specific trading companies. Trade activities related to commodities that are frequently stored 
in ports (such as oil and grain) are included in the port cluster.

The case studies-Rotterdam, Durban and the Lower Mississippi port cluster (LMPC) - have been selected because: they are the largest ports on their respective continents; they have a large gateway function; and they are important clusters in their particular region. The empirical results are based on desk research, interviews and a survey. In each port cluster, a list of port experts was made, and these experts were asked to participate, by making time for an interview and answering a set of survey questions. These survey questions were answered during the interview, so that questions and answers could be explained. Forty-three experts participated in Rotterdam, thirty-four in Durban and thirty-one in the LMPC. This is over four-fifths of all selected port experts, so the results from the survey and interviews are reliable. The survey questions address the validity of the variables, the importance of the variables, and the 'score' of each port cluster compared to a competing port cluster, for each variable. Rotterdam is compared with Antwerp and Hamburg; Durban with Richard's Bay and the LMPC with Houston. For all survey results, tests of statistical significance have been made.

As a first step of the case study research, the size of the three port clusters is analyzed. The available firm data in Rotterdam led to a small overestimation of the number of firms, since legal or fiscal ventures are included. Based on these data, Rotterdam's port cluster encompasses about 3,560 firms, $36 \%$ of which is active in transport and $45 \%$ in logistics. The number of manufacturing firms is limited (about 90) but they generate a substantial part of all value added in the cluster. The relevant cluster region consists of sixteen municipalities, of which Rotterdam and Dordrecht are the most important ones. In Durban, firm data are lacking, so the cluster population is identified on the basis of expert opinions and the Yellow Pages directory. This leads to a minor underestimation of the size of the cluster. Durban's port cluster consists of about 680 firms, to a large extent transport firms (48\%). The relevant region consists of six municipalities, of which Durban is by far the most important. The Lower Mississippi Port Cluster (LMPC) can be defined very precisely. The cluster consists of 1,168 firms. Transport is dominant and trade relatively well represented $(16 \%)$. The cluster region comprises twelve municipalities.

As the second part of the case studies research, the validity of the various variables is tested and the influence of the variables is further analyzed. The main results are given below, without presenting the underlying analysis of the survey results. These can be found in De Langen (2004).

\section{Agglomeration Economies}

The presence of customers and suppliers is a clear force towards concentration in all three ports. Furthermore, the experts in al three cases regard it as the most important agglomeration force. The presence of knowledge is also regarded as a force towards clustering in seaports.

The presence of labor was regarded as an agglomeration force in Rotterdam and the LMPC, but not in Durban, because of high unemployment and limited training efforts in this port. About half of the respondents in Rotterdam indicate that the high 
wage level in Rotterdam offsets the presence of labor. Congestion in seaports is not regarded as a force opposing agglomeration, but towards the dispersion of port activities away from the port. This also holds for high land prices. Thus, agglomeration economies dominate.

In all three cases, the port cluster would benefit from more establishments in logistics, manufacturing and trade. These activities cannot be attracted with only traditional location factors, such as accessibility and land availability. The two most important 'new' location factors for port clusters are 'the quality of life' in a port region, and the presence of a good knowledge infrastructure. Reducing the negative effects of transport flows, for instance by creating dedicated solutions for freight road transport, can enhance the quality of life. Furthermore, the redevelopment of old port areas is an opportunity to improve the quality of life.

The knowledge infrastructure increases the attractiveness of the port city for firms that employ high-skilled people. The knowledge requirement differs per port: in Rotterdam, petro-chemical knowledge infrastructure would fit, whereas in the LMPC and Durban, a logistics knowledge base would fit better.

\section{Internal Competition}

The presence of internal competition (competition between firms located in the port cluster) contributes to the performance of the port cluster, because:

- Internal competition prevents monopoly pricing, because the costs of switching between suppliers in the same port are low,

- Internal competition leads to specialization of firms in the cluster,

- Internal competition fosters innovation.

These conclusions hold in all three cases. The fierceness of internal competition is moderate in cargo handling and port services such as pilotage and towage. Only in the LMPC is internal competition in some cargo handling segments (break-bulk and dry bulk) fierce. This is partly explained by competition between port authorities in the LMPC, who have accommodated (and even invested in) redundant facilities.

With regard to the lack of competition in cargo handling, the challenge-in general terms - is to reconcile scale economies with competition. An arrangement could be to lease a terminal to two operators. In principle, two independent operators can use the same terminal. This arrangement is unstable if the two operators are headon competitors. However, when one operator offers 'multi-user services' while the other is self-handling a large liner shipping company, the arrangement could be stable. This arrangement increases competitive pressure, especially for the multi-user terminal since the dedicated terminal operator could start to offer services for third parties. Such an arrangement was discussed with the port experts in Durban and was regarded as a good arrangement to prevent monopolistic behavior.

\section{Cluster Barriers}

The presence of barriers to entry or barriers to exit limits the performance of port clusters. The most relevant entry barrier is the inaccessibility of knowledge and 
networks. The unavailability of 'local capital' is an entry barrier in Durban and the LMPC, but not in Rotterdam. The only relevant exit barrier is unrecoverable 'port specific investments'. This finding suggests a strategy to 'tie' firms to the cluster does not contribute to performance; rather, exit barriers should be reduced, for instance by leasing assets to firms in the port cluster.

The level of specific investments that have to be made depends on the possibilities to develop arrangements where specialized actors (including the port authority) make specific, long-term investments invest in assets that are leased to start-ups and entrants. Such arrangements include:

- Developing land and infrastructure and leasing this to the private sector. This activity is widely regarded as the primary role of port authorities, and essentially is nothing more than making specific investments to lower entry barriers for private firms. This policy is common practice in the port industry and is done in Rotterdam, the LMPC and Durban.

- Investing in specific assets, such as cranes, warehouses and special cargo facilities. These investments imply port authorities invest in the 'tool' and lease these to the private sector. This strategy leads to a reduction of entry barriers and can improve the performance of the port cluster. The port authorities in the LMPC and Rotterdam make such investments.

- The provision of office space in the port area for port related small and medium-sized enterprises (SMEs). 'Micro-clustering' of these firms in the same area has advantages, such as the presence of knowledge and networks. For these reason, port authorities can invest in a self-sustaining provider of office space for port related SMEs. Such an involvement is only valuable when the provision of adequate office space by the market is not effective, for instance because real estate investors are not willing to make initial investments. Rotterdam is the only one of the three ports where the port authority is involved in providing office space.

\section{Heterogeneity of the Cluster}

Heterogeneity contributes to performance, because it creates opportunities for innovation and cooperation. Furthermore, it reduces vulnerability for external shocks. A diverse mix of local firms, foreign owned firms and cluster based multinationals (diversity of international scope) and a diverse mix of economic activities are important in this respect. The LMPC is less diverse than Rotterdam and Durban.

An opportunity to improve the diversity of the cluster is through attracting new growth activities. In Rotterdam, the following growth activities have been identified (Welters and De Langen, 2003):

- Logistics, especially 'supply chain management' (Haynes et al, 1997).

- Industrial tourism.

- Waste processing and recycling.

- Maritime services. 
- Offshore construction and decomposition (RMPM, 2002).

- 'Postponed manufacturing'.

- The manufacturing of high value chemicals, such as medicine and bio-tech products.

- Port leisure.

- Education in port and transport related activities.

Coalitions - comprising both public and private actors- that aim to attract firms from these industries can be effective. In Rotterdam, such coalitions have developed to attract new manufacturing activities and offshore decomposition. However, initiating such coalitions is difficult because of the need to continue efforts for a long period of time, say up to 10 years, in the absence of short-term results.

\section{Trust}

Trust in the cluster contributes to performance. It is the most important 'governance variable'. Both the LMPC and Rotterdam are not 'high trust clusters', compared to their competitors. The level of trust in the port cluster in Durban is higher than in Richard's Bay. Since trust is based on a 'social relation', improving the social embedding of individuals in the port cluster is a method to improve trust. However, most experts are skeptical about initiatives to enhance the level of trust. Once a climate of trust has developed, it can be sustained.

One approach that could make sense is to try to develop 'community spirit' among young professionals in the port. In Rotterdam, a 'young roundtable' was developed, where young professionals meet about six times a year and discuss common themes. One of the objectives of this initiative is to make these professionals aware of the importance of common themes and to prepare them for later involvement in organizations (especially associations) that promote common interests. In the LMPC and Durban, initiatives to build trust are absent.

\section{Intermediaries}

The presence of intermediaries contributes to the performance of the port cluster, but is relatively unimportant compared to the other governance variables. The forwarder is regarded as the most important intermediary. Rotterdam is endowed with a large number of intermediaries. In the LMPC and Durban, intermediaries are not well represented.

\section{Leader Firms}

Leader firms are firms with the ability and incentives to make investments with benefits for other firms in the cluster. Leader firms generally have a good market position, an international scope and innovative capabilities. The presence of such firms in a cluster contributes to its performance. Rotterdam is endowed with relatively many leader firms, but the same is true for its competitors Antwerp and Hamburg. 
Durban has more leader firms than Richard's Bay, the LMPC lags behind Houston in this respect.

Leader firm involvement is in most cases a top management issue. Typical activities where a contribution of leader firms would make sense include:

- Attract financial resources for joint projects.

- Ensure political support for projects with substantial political involvement.

- Provide management expertise and best practices information.

Provision of a 'support infrastructure' can improve the ability of firms to act as leaders. This professional support infrastructure guarantees effective project management. In some cases, associations can provide this support infrastructure; in other cases setting up specific firm-to-firm linkages is more effective.

In Rotterdam, the support infrastructure is relatively good. This is one of the reasons for the relatively positive evaluation of the involvement of leader firms in the collective action regimes in Rotterdam. In the LMPC, the maritime cluster initiative, initiated by Metrovision, provides the support infrastructure that enables two leader firms to become involved. In Durban, the support infrastructure is not well developed.

\section{Collective Action Regimes}

Collective action regimes are required because individual firms tend to 'free ride' and consequently under invest in projects with collective benefits. This problem is relevant for investments in training and education, marketing, innovation, and hinterland access. All these regimes are important for the performance of port clusters. The following conclusions with regard to the quality of these regimes can be drawn:

- The hinterland access regime in Rotterdam is better than this regime in the LMPC and Durban. This is explained by the involvement of public organizations (especially the port authority) and leader firms in this regime (see De Langen and Chouly, 2003).

- The marketing and promotion regime in Durban is not effective, both governments and private firms are unwilling to contribute to the quality of the regime. In the LMPC, this regime depends largely on public actors, whereas in Rotterdam a good public-private arrangement has been created.

- The training and education regime is especially bad in the LMPC, leader firm involvement is lacking in this cluster. The regime is good in Rotterdam, because of the role of leader firms and the effective organizational infrastructure.

- The innovation regime is modest in all three ports, in Rotterdam because there is no 'community spirit'. The internationalization regime is also modest in all three cases.

- Leader firm involvement is an advantage for Rotterdam 'across the board'. 
All fifteen regimes that have been analyzed have shortcomings. Experts have indicated opportunities for improving all regimes. Table 3 shows the most frequently encountered opportunities to improve the regimes.

Table 3. Opportunities to improve collective action regimes

\begin{tabular}{l|l}
\hline Regime & Opportunity \\
\hline Hinterland access & $\begin{array}{l}\text { Improve market intelligence } \\
\text { Improve intermodal accessibility } \\
\text { Develop a network with hinterland nodes }\end{array}$ \\
\hline $\begin{array}{l}\text { Marketing and } \\
\text { promotion }\end{array}$ & $\begin{array}{l}\text { Developing a collective organization for marketing and promotion, with indirect } \\
\text { financing from the port authority }\end{array}$ \\
\hline $\begin{array}{l}\text { Training and } \\
\text { education }\end{array}$ & $\begin{array}{l}\text { Strategic cooperation to improve the quality of the training and education } \\
\text { infrastructure } \\
\text { Re-training to increase job mobility of employees in declining industries }\end{array}$ \\
\hline Innovation & $\begin{array}{l}\text { Knowledge transfer between small and large firms } \\
\text { A high volumes, low nuisance, freight road transport system }\end{array}$ \\
\hline Internationalization & Port representatives in important markets \\
\hline
\end{tabular}

\section{CONCLUSIONS}

This paper has presented the results of applying cluster theories to ports. It was shown that existing cluster theories yield many relevant insights that can fruitfully be applied to ports. A framework in which the most relevant insights are incorporated was presented. Furthermore, it was argued that ports are indeed cluster of economic activities related to the arrival of cargo and ships in seaports.

Finally, the results of analyzing the effects of the various relevant variables of the cluster's performance were presented, and implications for port management discussed. These implications for port managers are manifold and provide an interesting area for further research.

\section{REFERENCES}

Haezendonck, E. (2001) Essays on Strategy Analysis for Seaports, Leuven, Garant.

Haynes, K. E., King, Y. M. and Stough, R. R. (1997) "Regional port dynamics in the global economy: the case of Kaoshiung, Taiwan", Maritime Policy and Management, 24 (1) 1995 pp. 93-113.

Klink, H.A. van (1995) Towards the borderless Mainport Rotterdam - an analysis of functional, spatial and administrative dynamics in port systems, Amsterdam: Thesis publishers.

Krugman, P. (1991) Geography and Trade, Cambridge Massachusetts, The MIT Press 
Langen, P.W. de (2004) The performance of seaport clusters; a framework to analyze cluster performance and an application to the seaport clusters of Durban, Rotterdam and the Lower Mississippi, ERIM and TRAIL thesis series

Langen, P.W. de, and Nijdam, M.H. (2003) Leader firms in de Nederlandse Maritieme cluster; theorie en praktijk, Delft University Press, uitgave in de Nederland Maritiem Land serie

Langen, P.W. de, and Chouly, A. (2003) "Regimes portuares et acces a l'arriere-pays", Les Cahiers Scientifiques du Transport, 44 pp77-95

Metcalfe (1994) Competition, Fisher's Principle and Increasing Returns in the Selection Process, Journal of Evolutionary Economics, 4(4) pp. 327-346.

Nooteboom, B. (1999) Interfirm Alliances: Analysis and Design, London, Routledge.

Olson, M. (1971) The Logic of Collective Action: Public Goods and the Theory of Groups, Cambridge Massachusetts, Harvard University Press.

Porter, M.E. (1990) The Competitive Advantage of Nations, London, MacMillan.

RMPM (2002) Annual Report, Rotterdam.

Slack, B. (1989) "Port services, ports, and the urban hierarchy", Tijdschrift voor Economische en Sociale Geografie, 80 pp. 236-243.

Welters, H.W.H. en Langen, P.W. de (eds) (2003) Het onzekere voor het zekere nemen, een visie vanuit de wetenschap op de ontwikkeling van het haven-en industriecomplex Rotterdam op de lange termijn, Elsevier, Rotterdam. 